\title{
PREVALENSI DAN JENIS PENYAKIT YANG MENGINFEKSI KARANG DI PERAIRAN PULAU ENGGANO BENGKULU
}

\author{
Person Pesona Renta ${ }^{1}$, Dewi Purnama ${ }^{1}$, Bertoka Fajar SP Negara ${ }^{1}$, \\ Dwi Ari Yasinto Rahmantyo ${ }^{1}$, Nico Deodatus Adhi ${ }^{1}$, Raja Aditya \\ Sahala Siagian ${ }^{1}$, Aradea Bujana Kusuma ${ }^{2}$ \\ ${ }^{1}$ Program Studi Ilmu Kelautan, Fakultas Pertanian, Universitas Bengkulu, \\ Bengkulu, Indonesia \\ ${ }^{2}$ Program Studi IImu Kelautan, Fakultas Perikanan dan Kelautan, \\ Universitas Papua, Provinsi Papua Barat, Indonesia \\ E-mail :pprenta@unib.ac.id
}

Received March 2020, Accepted April 2020

\begin{abstract}
ABSTRAK
Penyakit karang merupakan salah satu permasalahan ekosistem terumbu karang yang diakibatkan oleh manusia. Penyakit karang dapat menyebabkan penurunan kualitas dan daya imun karang yang ditandai dengan terhambatnya laju pertumbuhan pada karang dan berdampak pada matinya karang di suatu perairan. Penelitian ini bertujuan untuk mengidentifikasi jenis penyakit dan bentuk pertumbuhan karang yang sering terinfeksi penyakit serta menganalisis prevalensi penyakit karang di Perairan Pulau Enggano, Bengkulu. Penelitian ini menggunakan metode survei. Pengambilan data penyakit karang dengan metode transek sabuk (Belt Transect). Hasil penelitian didapatkn 9 jenis penyakit yang ditemukan di Pulau Enggano, yaitu Yellow Band Desease, Black Band Desease, White Band Desease, Red Band Desease, Dark Plague, White Plague, Pink Plotch, dan Ulcerative White Spots, serta White Spot. Sedangkan bentuk pertumbuhan (lifeform) karang yang terinfeksi adalah Coral Massive dan Acropora Branching. Tingkat prevelensi karang tertinggi terdapat pada lokasi Kahabi, sedangkan terendah pada Pulau Dua di bagian windward. Tingginya tingkat prevalensi di Kahabi dimungkinkan karena tingginya kedalaman di lokasi tersebut. Rendahnya tingkat prevalensi karang pada Pulau Dua di sisi windward dimungkinkan karena pada sisi ini merupakan daerah yang terkena arus tiap saat, sehingga membantu karang dalam membersihkan sedimen yang menempel pada permukaan yang dimungkinkan membawa bakteri penyebab penyakit karang.
\end{abstract}

Kata Kunci : Terumbu Karang, Prevalensi, Penyakit Karang, Pulau Enggano. 


\begin{abstract}
CORAL DISEASE PREVALENCE IN ENGGANO ISLAND, BENGKULU. Coral disease is one of the coral reef ecosystem problems caused by humans. Coral disease causes a decrease in the quality and immunity of corals characterized by stunted growth rates on corals and impacts on the death of corals in waters. This study aims to identify the types of coral disease and coral lifeform that are often infected and analyze the prevalence of coral disease in Enggano Island Waters, Bengkulu. This research used survey method. Coral disease data were obtained using the belt transect method. The results obtained 9 types of coral diseases found on Enggano Island, namely Yellow Band Desease, Black Band Desease, White Band Desease, Red Band Desease, Dark Plague, White Plague, Pink Plotch, and Ulcerative White Spots, and White Spot. While infected lifeforms were Coral Massive and Acropora Branching. The highest level of coral prevalence was at the Kahabi site, while the lowest was on Pulau Dua in the windward area. The high prevalence rate in Kahabi might be due to the high depth at the location. The low level of coral prevalence on Pulau Dua on the windward side might be caused by being exposed to the current at any time, thus helping the coral in cleaning sediments attached to the surface which could carry the bacteria that cause coral disease.
\end{abstract}

Keywords : Coral Reef, Prevalence, Coral Disease, Enggano Island

\title{
PENDAHULUAN
}

Penyakit karang merupakan sumber kerusakan yang dapat penghambat laju pertumbuhan dan kematian pada populasi karang. Penyakit karang ditandai dengan adanya perubahan warna, kerusakan dari jaringan karang, sampai dengan hilangnya jaringan karang. Penyakit karang merupakan gangguan ketahanan fisik terumbu karang yang disebabkan oleh serangan virus atau bakteri sehingga memicu kerusakan pertumbuhan pada ekosistem terumbu karang yang terinfeksi. Menurut Nirwanda dkk., (2017) penyakit karang didefinisikan sebagai sesuatu kegagalan fungsi vital hewan karang, organ atau sistem, penghentian pertumbuhan dan perkembangbiakan atau kegagalan fungsi lainnya. Beberapa jenis penyakit karang yang umum dijumpai dan masih terus dilakukan pengamatan diantaranya penyakit Black Band Disease, Dark Spots Disease, Red Band Disease, White Band Disease, White Plague, White Pox, Yellow Band Disease (Siringoringo, 2007). Beberapa faktor timbulnya penyakit pada karang disebabkan oleh adanya perubahan lingkungan dan adanya pencemaran limbah antropogenik.

Limbah antropogenik yang mencemari ekosistem terumbu karang dapat memicu infeksi karang. Polusi sampah laut seperti sampah plastik, logam, kaca, dan kertas diduga sebagai salah satu penyalur terhadap penyakit terumbu karang (Harrison et al., 2011). Berdasarkan penyebabnya, penyakit karang dapat digolongkan menjadi dua, yakni infeksi pathogen dan non infeksi. Pathogen dapat berasal dari 
mikroparasit seperti virus, bakteri, jamur. Sedangkan non infeksi dapat berupa meningkatnya suhu air laut, sedimentasi dan polutan (Siringoringo, 2007).

Penyakit karang dapat menyebabkan penurunan kualitas dan daya imun karang yang ditandai dengan terhambatnya laju pertumbuhan pada karang dan akan meyebabkan matinya populasi karang di suatu perairan (Nirwanda $d k k$., 2017). Selain itu juga Penyakit karang berdampak pada penurunan kapasitas reproduksi karang (Johan, 2010). Ciri-ciri karang yang terinfeksi penyakit akan terlihat ada bagian koloni yang mengalami luka atau perbedaan band dari jaringan karang yang hilang, hal ini dapat disebabkan oleh bakteri, virus, protozoa atau jamur (Nirwanda dkk., 2017). Kematian karang akibat terinfeksi oleh bakteri banyak dilaporkan hingga saat ini (Yamashiro, 2004; Johan, 2010; Ardiansyah et al., 2013; Rahmi, 2014; Dedi et al, 2017). Dampak penyakit karang yang ditimbulkan tersebut dapat diamati ke dalam prevalensi penyakit karang. Prevalensi penyakit karang dilakukan untuk mengetahui perhitungan jumlah koloni karang yang terinfeksi penyakit dari jumlah total karang karang diperiksa, dari hasil perhitungan prevalensi ini akan mendapatkan jenis penyakit yang menginfeksi pada suatu koloni karang.

Saat ini penelitian tentang tutupan terumbu karang telah dilakukan oleh Zamdial dkk, 2016 di Pulau Enggano. Muqsit dkk, 2016 juga telah meneliti tentang struktur komunitas terumbu karang di Pulau Dua, Pulau Enggano. Selain itu, Cahyadinata , 2009 telah meneliti tentang kesesuaian pengambangan wisata Pulau Enggano dan perikanan tangkapnya. Sedangkan penelitian tentang identifikasi penyakit karang di Pulau Enggano belum pernah dilakukan. Oleh karena itu penelitian ini penting untuk dilakukan untuk mendapatkan data tentang jenis penyakit dan juga tingkat prevalensi karang di ekosistem terumbu karang.

\section{MATERI DAN METODE}

\section{Waktu dan Tempat Pengambilan Sampel}

Penelitian ini dilakukan pada bulan September 2018 di perairan Kahabi dan Berhau Desa Banjarsari Pulau Enggano serta daerah leeward dan winward Pulau Dua. Peta lokasi penelitian tersaji pada Gambar 1.

\section{Metode Pengumpulan Data}

Metode yang digunakan dalam penelitian ini menggunakan metode survei. Metode survei dapat menggambarkan kondisi penyakit pada karang (Suharsono, 1994). Data yang diperoleh kemudian di analisa dan di interpretasikan menggunakan metode deskriptif. Menurut Suryana (2010), Metode deskriptif adalah metode yang digunakan untuk menjelaskan data yang diperoleh pada saat penelitian. Metode ini dimulai dengan mengumpulkan data, menganalisis data dan menginterpretasikannya. 


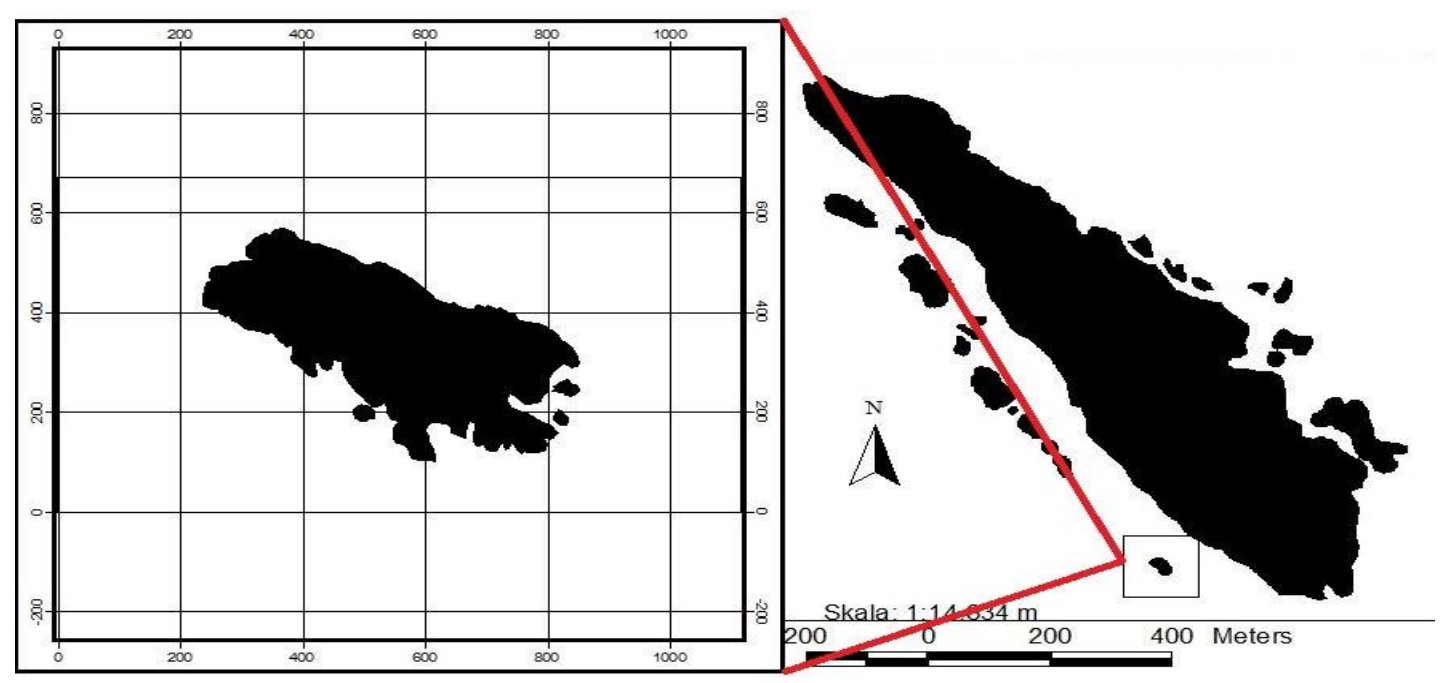

Gambar 1. Peta Lokasi Penelitian

\section{Prosedur Pengambilan Data}

\section{Tahap Persiapan}

Tahap persiapan yang dilakukan meliputi pengumpulan informasi awal mengenai kondisi lokasi penelitian dan dijadikan pedoman pada saat pengambilan data prevalensi dan tingkat kehadiran penyakit karang dilapangan.

\section{Penetapan Lokasi Penelitian}

Penetapan lokasi penelitian berdasarkan karakteristik dan kondisi suatu wilayah perairan, serta keberadaaan koloni karang disuatu perairan. Lokasi penelitian berada pada empat tempat di perairan Pulau Enggano, yaitu Pulau Dua leeward, Pulau Dua, windward, perairan Berhau dan Kahabi dengan kedalaman berkisar dua hingga dua puluh satu meter. Penentuan titik pengambilan data lapangan menggunakan metode purposive sampling.

\section{Pengambilan Data Bentuk Pertumbuhan dan Penyakit Karang}

Pengambilan data penyakit karang menggunakan metode transek sabuk (Belt Transect). Pada lokasi penelitian terdapat 1 stasiun, didalam 1 stasiun terdapat 3 transek dengan modifikasi plot $5 \times 2$ meter pada setiap transek. Pada 1 transek terdapat 5 kali pengulangan. Panjang 1 transek berukuran 25 meter dengan lebar sisi kiri dan sisi kanan berukuran 2 meter serta jarak antar stasiun berukuran 5 meter. Gambar transek yang akan digunakan disajikan pada gambar 2 . 


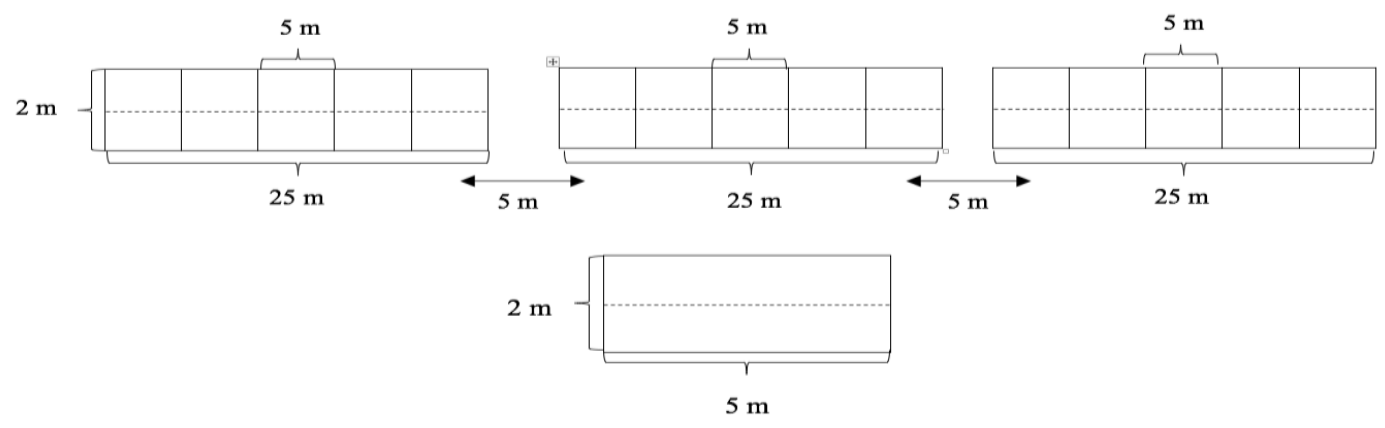

Gambar 2. Belt Transect yang digunakan dalam penelitian

\section{Parameter Perairan}

Parameter lingkungan yang diukur pada saat penelitian adalah suhu, salinitas, arus, kecerahan, $\mathrm{pH}$ dan kedalaman.

\section{Analisis Data}

Identifikasi bentuk pertumbuhan karang menggunakan buku The Indo Pacific Coral Finder (Kelley, 2009). Identifikasi jenis penyakit karang menggunakan buku Coral Disease Handbook Guidelines for Assessment, Monitoring and Management (Raymundo et al., 2008). Perhitungan prevalensi penyakit karang dilakukan dengan mengacu pada Raymundo et al., (2008). Prevalensi penyakit terhadap karang dapat dihitung dengan menggunakan rumus sebagai berikut:

$$
\text { Prevalensi }=\frac{n}{N} \times 100 \%
$$

Keterangan:

$\mathrm{n} \quad=$ Jumlah karang yang terinfeksi penyakit

$\mathrm{N} \quad=$ Jumlah karang yang diperiksa

\section{Tingkat Kehadiran Penyakit Karang}

Tingkat kehadiran penyakit karang dianalisis menggunakan metode deskriptif. Metode ini dimulai dengan mengumpulkan data, menganalisis data dan menginterpretasikannya.Tingkat kehadiran penyakit karang dilihat dari jumlah suatu koloni karang yang terinfeksi penyakit dan jenis penyakit apa yang menginfeksi koloni karang yang paling mendominasi disuatu perairan. Menurut Odum (1993), untuk mengetahui tingkat kehadiran penyakit karang dilakukan perhitungan dengan rumus sebagai berikut:

Keterangan:

$$
X i=\frac{x_{i}}{n} \times 100 \%
$$

$\mathrm{Xi} \quad=$ Tingkat kehadiran penyakit karang $\mathrm{ke}-\mathrm{i}$

$x_{i} \quad=$ Jumlah jenis penyakit karang yang sama

$\mathrm{n} \quad=$ Total jumlah plot dalam transek 


\section{Parameter Perairan}

Parameter perairan disajikan dalam bentuk tabulasi dan dijelaskan dengan metode deskriptif, dengan tujuan untuk mengetahui keterkaitan antara parameter perairan dengan penyakit karang.

\section{HASIL DAN PEMBAHASAN}

Tabel 1.

Prevalensi penyakit karang di Pulau Enggano dapat dilihat pada

Tabel 1. Tingkat Kehadiran Penyakit dan Prevalensi Penyakit Karang di Pulau Enggano

\begin{tabular}{|c|c|c|c|c|c|c|c|c|c|c|c|c|c|c|c|c|}
\hline \multirow[b]{3}{*}{$\begin{array}{l}\text { Jenis Karang } \\
\text { Terjangkit }\end{array}$} & \multirow{2}{*}{\multicolumn{3}{|c|}{$\begin{array}{c}\text { Palau Dua, Leeward } \\
\text { Jenis Penyakit }\end{array}$}} & \multirow{2}{*}{\multicolumn{3}{|c|}{$\begin{array}{c}\text { Palau Dua, Windward } \\
\text { Jenis Penyakit }\end{array}$}} & \multicolumn{5}{|c|}{ Berhau } & \multicolumn{5}{|c|}{ Kahabi } \\
\hline & & & & & & & \multirow[b]{2}{*}{$\begin{array}{l}\text { White } \\
\text { Pla- } \\
\text { gue }\end{array}$} & \multicolumn{3}{|c|}{ Jenis Penyakit } & \multirow[b]{2}{*}{$\begin{array}{l}\text { Ulce- } \\
\text { rative } \\
\text { White } \\
\text { Spots }\end{array}$} & \multirow[b]{2}{*}{ RBD } & \multicolumn{3}{|c|}{ Jenis Penyakit } & \multirow[b]{2}{*}{$\begin{array}{l}\text { White } \\
\text { Spot }\end{array}$} \\
\hline & YBD & BBD & $\begin{array}{l}\text { Dark } \\
\text { Plague }\end{array}$ & $\begin{array}{l}\text { White } \\
\text { Pla- } \\
\text { gue }\end{array}$ & WBD & $\mathrm{BBD}$ & & $\mathrm{BBD}$ & YBD & $\begin{array}{l}\text { Pink } \\
\text { Plotch }\end{array}$ & & & BBD & $\begin{array}{l}\text { Ulcera- } \\
\text { tive } \\
\text { White } \\
\text { Spots }\end{array}$ & YBD & \\
\hline $\begin{array}{l}\text { Acropora } \\
\text { Branching }\end{array}$ & $\sqrt{ }$ & & & $\sqrt{ }$ & $\sqrt{ }$ & & $\sqrt{ }$ & & & & & & & & & \\
\hline Coral Massive & & $\sqrt{ }$ & $\sqrt{ }$ & $\sqrt{ }$ & & $\sqrt{ }$ & $\sqrt{ }$ & $\sqrt{ }$ & $\sqrt{ }$ & $\sqrt{ }$ & $\sqrt{ }$ & $\sqrt{ }$ & $\sqrt{ }$ & $\sqrt{ }$ & $\sqrt{ }$ & $\sqrt{ }$ \\
\hline $\begin{array}{l}\text { \% Preverensi } \\
\text { Jenis Penyakit }\end{array}$ & $\begin{array}{c}0.61 \\
\%\end{array}$ & $\begin{array}{c}4.29 \\
\%\end{array}$ & $0.61 \%$ & $0.13 \%$ & 0.81 & 0.27 & $\begin{array}{c}0.52 \\
\%\end{array}$ & $\begin{array}{c}1.22 \\
\%\end{array}$ & $\begin{array}{c}0.69 \\
\%\end{array}$ & $1.22 \%$ & $\begin{array}{c}0.34 \\
\%\end{array}$ & $\begin{array}{c}1.17 \\
\%\end{array}$ & $\begin{array}{c}1.75 \\
\%\end{array}$ & $1.75 \%$ & $\begin{array}{c}2.34 \\
\%\end{array}$ & $\begin{array}{c}0.58 \\
\%\end{array}$ \\
\hline $\begin{array}{l}\text { \% Total } \\
\text { Preverensi } \\
\text { Karang } \\
\text { berpenyakit }\end{array}$ & & $5.52 \%$ & & & $1.22 \%$ & & & & $4.02 \%$ & & & & & $7.60 \%$ & & \\
\hline $\begin{array}{l}\text { \% Total } \\
\text { Preverensi } \\
\text { Karang Sehat }\end{array}$ & & 94.47 & & & $98.77 \%$ & & & & $94.59 \%$ & & & & & $92.40 \%$ & & \\
\hline
\end{tabular}

Keterangan: YBD : Yellow Band Desease

BBD : Black Band Desease

WBD : White Band Desease

RBD : Red Band Desease

\section{Lifeform Karang yang Terinfeksi dan Jenis Penyakit yang Menginfeksi}

Total terdapat 9 jenis penyakit yang ditemukan di Pulau Enggano. Jenis-jenis penyakit yang dijumpai di perairan Pulau Enggano adalah Yellow Band Desease, Black Band Desease, White Band Desease, Red Band Desease, Dark Plague, White Plague, Pink Plotch, dan Ulcerative White Spots, serta White Spot (Tabel 1). Jumlah kehadiran jenis penyakit karang di Pulau Enggano tertinggi di lokasi Berhau dan Kahabi. Di Berhau ditemukan 5 jenis penyakit yaitu White Plague, Black Band Disease, Yellow Band Disease, Pink Plotch dan Ulcerative White Spots. Di Kahabi ditemukan 5 jenis yaitu Red Band Disease, Black Band Disease, Ulcerative White Spots, Yellow Band Disease, White Spot. Terendah di Pulau Dua leeward yaitu sebanyak 3 jenis penyakit yaitu Yellow Band Disease, Black Band Disease, Dark Plague. Di Pulau Dua bagian 
windward ditemukan sebanyak 3 jenis penyakit yaitu White Plague, Black Band Disease dan White Band Disease.

Black Band Disease merupakan salah satu penyakit yang kehadirannya paling tinggi diantara penyakit yang lain diseluruh lokasi penelitian. Penyakit ini merupakan salah satu penyakit yang sering dijumpai di ekosistem terumbu karang. Black Band Disease menginfeksi karang di beberapa perairan yaitu di Great Barrier Reef (Dinsdale, 2000), dan di Laut Merah, Mesir menginfeksi karang Acropora (Mohamed et al., 2010). Infeksi BBD ini juga ditemukan di perairan Indonesia antara lain di Pulau di Karimunjawa menginfeksi Acropora sp (Sabdono dan Radjasa, 2004), di Kepulauan Seribu menginfeksi Montipora spp (Johan, 2014) dan di Pulau Barranglompo Sulawesi Selatan menginfeksi Pachyseris sp. dan Montipora sp. (Massinai, 2012).

Berdasarkan Hasil dari pengamatan pada Tabel 1 bentuk pertumbuhan karang yang terinfeksi penyakit karang yaitu Acropora Branching dan Coral Massive. Acropora Branching merupakan bentuk pertumbuhan karang yang paling sedikit terinfeksi jenis penyakit karang, sedangkan Coral Massive bentuk pertumbuhan karang yang memiliki jumlah karang yang terinfeksi jenis penyakit yang paling banyak terinfeksi penyakit karang. Hal ini dikarenakan Coral Massive memiliki sistem imun yang rendah dan bentuknya yang keras juga luasan permukaanya lebih besar dibandingkan jenis pertumbuhan karang yang lain membuat bakteri jenis cyanobacteria dan virus jenis vibrio charcharii, sphingomonoas $s p$, dan Aurantimonas Corallicida yang merupakan agen dari penyakit karang bisa mudah untuk menempel (Sweet $d k k$., 2011).

Hal ini sesuai dengan hasil penelitianya Handayani dkk., (2017) di Perairan Malang Selatan bahwa penyakit karang teramati mayoritas juga berada di Coral Massive. Menurut Hazrul, (2016) Coral Massive yang bentuknya yang padat dan berupa bongkahan bulat memungkinkan ikanikan predator jenis ikan kakak tua yang memakan jaringan karang, hal ini bisa menjadi daya dukung untuk menimbulkan penyakit. Bahkan ada jenis biota lain yaitu cacing pengebor (Raymundo dkk., 2008) yang menggangu kesehatan pada Coral Massive. Sedangkan Acropora Branching paling sedikit terinfeksi di karenakan bentuknya yang bercabang dan lebih ramping sehingga lebih mudah dilewati oleh pergerakan arus yang memicu hilangnya partikel-partikel sedimen penyebab penyakit yang mengendap di polip karang. Hal ini sesuai dengan pernyataan dari Rahmitha dkk., (2015) Yang menyatakan bahwa bentuk pertumbuhan karang Acropora Branching yang bercabang sehingga memudahkan arus untuk membersihkan sedimen yang menempel pada permukaan karang.

Tabel 2. Parameter Lingkungan Perairan Pulau Enggano

\begin{tabular}{llllll}
\hline No & $\begin{array}{l}\text { Parameter } \\
\text { Lingkungan }\end{array}$ & $\begin{array}{l}\text { Pulau } \\
\text { Dua } \\
\text { windward }\end{array}$ & $\begin{array}{l}\text { Pulau Dua } \\
\text { leeward }\end{array}$ & Berhau & Kahabi \\
\hline 1 & Suhu & $28^{0} \mathrm{C}$ & $28,7^{0} \mathrm{C}$ & $27,8^{0} \mathrm{C}$ & 27.9 \\
2 & Salinitas & $37 \mathrm{PPT}$ & $38 \mathrm{PPT}$ & $39 \mathrm{PPT}$ & 37 PPT \\
\hline
\end{tabular}




\begin{tabular}{llllll}
\hline No & $\begin{array}{l}\text { Parameter } \\
\text { Lingkungan }\end{array}$ & $\begin{array}{l}\text { Pulau } \\
\text { Dua } \\
\text { windward }\end{array}$ & $\begin{array}{l}\text { Pulau Dua } \\
\text { leeward }\end{array}$ & Berhau & Kahabi \\
\hline 3 & Ph & 8,1 & 8,2 & 8,2 & 8.1 \\
4 & Arus & $12 / 5 \mathrm{~m}$ & $09,41 / 5 \mathrm{~m}$ & $27,6 / 5 \mathrm{~m}$ & 15.8 \\
5 & Kecerahan & 100 & 100 & 100 & 100 \\
6 & Kedalaman & 3 & 2 & 4 & 21 \\
& & $\mathrm{~S}^{0} 26.8$ & $\mathrm{~S}^{0} 25^{0} 26.55^{\prime}$ & $\mathrm{S}^{0} 5^{0} 18.357^{\prime}$ & $\mathrm{S}^{0} 16.565^{\prime}$ \\
7 & Titik & $97^{\prime}$ & $\mathrm{E} 102^{0} 23.04$ & $\mathrm{E} 102^{0} 07.62$ & $\mathrm{E}^{\prime} 102^{0} 08.62$ \\
& Koordinat & $\mathrm{E} 102^{0} 23$. & $1^{\prime}$ & $4^{\prime}$ & $2^{\prime}$ \\
& $684^{\prime}$ & & & \\
\hline
\end{tabular}

\section{Prevalensi Penyakit Karang di Pulau Enggano}

Tingkat Prevelensi penyakit karang tertinggi terdapat di lokasi Kahabi yaitu mencapai 7.60\%, Pulau Dua leeward 5.52\%, Berhau $4.02 \%$ dan Pulau Dua windward sebesar $1.22 \%$. Tingginya tingkat prevalensi penyait karang di Perairan Kahabi dimungkinkan karena tingginya kedalaman pada lokasi ini (Tabel 2). Kedalaman yang tinggi menyebabkan penetrasi cahaya yang masuk semakin berkurang yang dapat berdampak pada menurunnya proses fotosintesis zooxanthellae yang bersimbiosis dengan karang sehingga membatasi asupan makanan yang diberikan oleh zooxanthellae pada karang. Hal tersebut dapat mengakibatkan menurunnya proses metabolisme karang yang dapat berdampak pada menurunnya tingkat imunitas karang. Tingkat imunitas yang rendah dapat menyebabkan karang mudah terinfeksi penyakit. Nirwanda dkk., 2017 menyebutkan bahwa penyakit karang dapat menyebabkan menurunnya kualitas dan daya imun karang yang ditandai dengan terhambatnya laju pertumbuhan pada karang dan akan meyebabkan matinya populasi karang di suatu perairan.

Rendahnya tingkat prevalensi karang pada Pulau Dua di sisi windward dimungkinkan karena pada sisi ini merupakan daerah yang terkena arus tiap saat, hal ini dapat membantu karang untuk membersihkan sedimen yang menempel pada permukaan karang yang dimungkinkan membawa bakteri penyebab penyakit karang. Pada sisi ini terumbu karang dapat hidup baik karena pengaruh sirkulasi air yang mengalir pada sisi ini. Pada sisi windward atau daerah yang langsung terkena angin, sirkulasi airnya sangat bagus. Sehingga karang mampu tumbuh subur pada sisi ini. Menurut Nybakken (1992) sirkulasi air sangat penting bagi terumbu karang karena berhubungan dengan penyediaan oksigen dan makanannya dalam bentuk zooplankton, serta dalam membersihkan permukaan karang dari sedimen. Hal ini dibuktikan juga oleh penelitian Kusuma et al, 2018 yang menyatakan bahwa terumbu karang akan hidup dengan baik dan keanekaragamannya akan tinggi jika berada pada lokasi windward.

Tingkat prevalensi penyakit karang di Perairan Pulau Enggano jika dibandingkan dengan penelitian Dedi dkk, (2016) di pulau-pulau kecil Teluk Jakarta, Subhan et all, 2011 di Perairan Pulau Pramuka, Kepulauan 
Seribu, dan Handayani et al., 2017 di Perairan Kondang merak, tergolong rendah. Hal ini menandakan bahwa secara imunitas, kekebalan tubuh atau kesehatan dari karang di Perairan Enggano masih dikategorikan dalam kondisi bagus. Hal ini dimungkinkan Pulau Enggano merupakan salah satu pulau kecil terluar Indonesia yang lingkungannya masih terjaga baik dan masih belum banyak pencemaran yang terjadi di perairannya. Walaupun hal ini bertentangan dengan penelitian tentang tingkat tutupan karang di Perairan Pulau Enggano yang telah dilakukan oleh Zamdial et al, 2016 yang menyatakan bahwa kondisi tutupan karang di Pulau Enggano masuk dalam kondisi yang buruk hingga sedang.

\section{KESIMPULAN}

Berdasarkan hasil penelitian dapat disimpulkan bahwa terdapat 9 jenis penyakit yang ditemukan di Pulau Enggano yaitu Yellow Band Desease, Black Band Desease, White Band Desease, Red Band Desease, Dark Plague, White Plague, Pink Plotch, dan Ulcerative White Spots, serta White Spot. Sedangkan bentuk pertumbuhan (lifeform) karang yang terinfeksi adalah Coral Massive dan Acropora Branching. Tingkat prevalensi karang tertinggi terdapat pada lokasi Kahabi, sedangkan terendah pada Pulau Dua di bagian windward. Rendahnya tingkat prevalensi karang pada Pulau Dua di sisi windaward dimungkinkan karena pada sisi ini merupakan daerah yang terkena arus tiap saat, sehingga membantu karang dalam membersihkan sedimen yang menempel pada permukaan yang dimungkinkan membawa bakteri penyebab penyakit karang.

\section{DAFTAR PUSTAKA}

Ardiansyah E.K., Hartoni, dan L. Litasari. 2013. Kondisi Tutupan Terumbu Karang Keras dan Karang Lunak di Pulau Pramuka Kabupaten Administratif Kepulauan Seribu DKI Jakarta. Journal Maspari. 5(2): 111-118.

Cahyadinata, Indra. 2009. Kesesuaian Pengembangan Kawasan Pesisir Pulau Enggano Untuk Pariwisata Dan Perikanan Tangkap. Jurnal AGRISEP. 9(2): 168-182.

Dedi dan T. Arifin. 2017. Kondisi Kesehatan Karang di Pulau - Pulau Kecil Teluk Jakarta. Jurnal Kelautan. 11(3): 175-187.

Dedi., Arifin. T. 2016. Kondisi Kesehatan Karang Di Pulau - Pulau Kecil Teluk Jakarta. Jurnal kelautan nasional. 11(3):175-187. 
Dinsdale, E.A. 2000. Abundance ofblack band disease on coral fromone location on the great barrierreef: a comparison withabundance in the carribeanregion. In Proceeding 9th International Coral Reef Symposium, Bali Indonesia. Journal Enviromental science. (2):1239-1243.

Handayani, M., Semedi, B., Asadi, M. A., Herdiutami, M., Novakandi, R., dan Zakiyah. 2017. Prevalensi Penyakit Karang White Band Disease (Wbd) Di Perairan Malang Selatan, Jawa Timur. Program Studi Ilmu Kelautan, Universitas Brawijaya Malang.

Harrison, J. P., Sapp, M., Schratzberger M dan Osborn,A.M. 2011. Interactions between Microorganisms and Marine Microplastics: a call for research. Journal Mar Tech Socie. 45:12-20.

Hazrul, H., Palupi.R.D., dan Ketjulan, R. 2016. Identifikasi Penyakit Karang (Scleractinia) Di Perairan Pulau Saponda Laut, Sulawesi Tenggara. Jurnal sapa laut. 1(2):32-41.

Johan, O. 2010. Penyebab, dampak dan managemen penyakit karang di ekosistem terumbu karang (Cause, impact and management of coral disease on coral reefs ecosystem). Media akuakultur. 5(2):144-152.

Johan, O., M. Delpop., S. A. Putra., F. Hadi., R. H. Putri., R. F., dan N. P. Zamani. 2014. Prevalensi Penyakit karang Di Windward Dan Leeward Pulau Pari, Kepulauan Seribu, Jakarta. Jurnal Prosiding Forum Inovasi Teknologi Akuakultur. 1089-1094.

Kelley, R. 2009. The Indo Pacifik Coral Finder. BYOGuides Townville, Australia.

Kusuma, AB., E.R. Ardli., R.E. Prabowo. 2018. The Diversity Of Stony Coral And The Tendency To Bleach Based On Lifeform In The Tengah Patch-Reef Of Karimunjawa Islands. Scripta Biologica. 5 (1): 13-18.

Massinai, A., Tondok, A.R. , Tahir, A., Jompa, J. 2012. Prevalensi Penyakit dan Gangguan Kesehatan pada Karang di Pulau Barranglompo. Disampaiakan pada Konas VIII, 22-24 Oktober. Mataram.

Mohamed, A. R., A. A. M. Ali, H. A. Abdel Salam. 2012. Status of Coral Reef Health in The Northern Read Sea, Egypt. Proceeding of The 12th International Coral Reef Symposium, Caims, Australia. 
Muqsit, A., D. Purnama., Z. Ta'alidin. 2016. Struktur Komunitas Terumbu Karang Di Pulau Dua Kecamatan Enggano Kabupaten Bengkulu Utara. Jurnal Enggano. 1(1): 75-87.

Nirwanda, S., W. Adi., dan I. A. Syari. 2017. Inventarisasi Penyakit karang Di Perairan Turun Aban Kabupaten Bangka. Jurnal Sumberdaya Perairan. 11 (1) : 18-25.

Nyabaken JW. 1992. Biologi Laut, Suatu Pendekatan Ekologis. Terjemahan: H.M. Eindman, Koesoebiono, D.G Bengen, M Hutomo, S Sukardjo. Gramedia. Jakarta. 459 p.

Odum, E.P. 1993. Dasar-dasar ekologi (terjemahan). Gadjah Mada University Press. Yogyakarta. 574hlm.

Rahmi. 2014. Prevalensi Penyakit Karang di Kawasan Konservasi Laut Daerah Di Sulawesi Selatan. Jurnal IImu Perikanan. 3(2): 287-296.

Rahmitha, I. A., Ruswahyuni., dan Suryanti. 2015. Laju Sedimentasi Pada Karang Massive Dan Karang Bercabang Di Perairan Pulau Panjang Jepara. Journal Of Maquares. 4(2) 9-16.

Raymundo, L. J., Couch, C. S., \& Harvell, C. D. (Eds). 2008. Coral Disease Handbook; Guidelines For Assessment, Monitoring \& Management. The Coral Reef Targeted Research \& Capacity Building for Management (CRTR).

Sabdono, A. dan Radjasa,.O.K 2006. Karakterisasi Molekuler Bakteri yang Berasosiasi dengan penyakit BBD (Black Band Disease). Pada karang Acropora sp. Di perairan Karimun Jawa.Ilmu Kelautan 11 (3) : $158-162$.

Siringoringo, R. M. 2007. Pemutihan Karang Dan Beberapa Penyakit Karang. Jurnal Oseana. 32(4):29-37.

Subhan, B., Rahmawati, F., Arafat, D., dan Bayu. N. A. 2011. Kondisi Kesehatan Karang Fungiidae Di Perairan Pulau Pramuka, Kepulauan Seribu. Jurnal Teknologi Perikanan dan Kelautan. 2(1):41-50.

Suharsono. 1994. Metode Penelitian Terumbu Karang. Pelatihan Metode Penelitian dan Kondisi Terumbu Karang. Materi Pelatihan Metodologi Penelitian Penentuan Kondisi Terumbu Karang.

Suryana. 2010. Metodologi Penelitian Model Praktis Penelitian Kuantitatif dan Kualitatif. Universitas Pendidikan Indonesia. 
Sweet, M. J., Bythell, J. C., dan Jones, R. 2011. Coral Diseases In Aquaria In Nature. Journal of the marine. 92(4):1-11.

Yamashiro, H. 2004. Coral Disease. Coral Reef of Japan. Edited by The Japanese Coral Reef Society and Ministry of the Environment. Ministry of the Environment of Japan.

Zamdial., A.B. Kusuma., D. Bakhtiar. 2016. Percent Cover Condition Of Coral Reef At West Coastal Of Enggano Island. International Seminar sustainable utilization of coastal resources in tropical zone, Bengkulu, Indonesia. Hal 167-173 